\title{
Seeing like the stateless: Documentation and the mobilities of liminal citizenship in Cambodia
}

\author{
Laurie Parsons and Sabina Lawreniuk
}

King's College London

This paper explores de facto statelessness amongst ethnically Vietnamese communities in Cambodia. It demonstrates that the inaccessibility of citizenship rights is not rooted directly in what documents an individual possesses, but in collective mobilities driven by a combination or past and present and potential risks. Specifically, the reluctance of officials to replace documents for those they perceive not to be ethnically Khmer means that even ethnically Vietnamese Cambodians possessing a full set of documents - and who have never crossed a border - are encouraged to pursue similar mobilities to those who have none, including first generation immigrants. The higher level of environmental risk associated with these ethnically mediated, informal livelihoods further reduces these households' stocks of physical documentation, inducing a reliance on social networks that are vulnerable to evictions and harassment. On this basis, this paper proposes the category of liminal statelessness, in order to better conceptualize a situation in which people with different legal statuses and abilities to prove them share livelihoods characterized by the non-exercise of citizenship rights.

\section{Introduction}

Cambodia's long cultivated repeated myth of homogeneity (Ter Horst, 2008; Edwards, 2007) disguises an inconvenient truth. Though less diverse than many of its Southeast Asian neighbours (Ovensen et al., 1996), Cambodia is far from uniform, either linguistically, ethnically or culturally. In fact, the Kingdom's predominantly ethnic Khmer population is accompanied by numerous minority groups, the largest of which is an ethnically Vietnamese population comprising almost 500,000 of the Kingdom's 15 million people (Rumsby, 2015). Nevertheless, their presence goes almost entirely without note in a legal framework wherein "Khmer" and "Cambodian" are used synonymously (Sperfeldt, 2017), leaving Cambodia with amongst the highest proportion of stateless persons in the world (ISI, 2014).

Despite their numbers, though, Cambodia's stateless ethnically Vietnamese population is historically diverse and geographically dispersed. Many have never crossed a border, but the complex history of migration and domination - which reached a peak during the upheaval and bloodshed of the 1970s and 
its aftermath - has left their communities with a patchwork of documentation whose impacts are felt across generations. For those thus afflicted, citizenship is therefore not an absolute state, but a question of degree (Ang et al., 2014; Sperfeldt and Nguyen, 2012), rooted more in the everyday judgments of ethnicity enacted by officials than such abstractions as legal status and entitlement. Statelessness for ethnically Vietnamese populations is therefore continually re-entrenched by shared practices of mobility which help to circumvent these forms of administrative marginality, but also mark out those who undertake them as subject to uncertain citizenship. Referred to here as collective mobilities, these practices of movement become a key form of distinction between those whose legal status is secure and those whose isn't.

These everyday, practiced, nuances of statelessness are, however, little noted in a literature dominated by legalistic frameworks, leaving the full 'complexity and gravity of the problem of statelessness' (Van Waas, 2009: 133) underexplored. In particular, the category of 'de facto' statelessness remains unclearly delineated, especially in its relationship to limited or ineffective citizenship. This paper therefore proposes the category of liminal statelessness, a conceptualization that focuses on the gray areas between citizenship and statelessness, in order to highlight the multiple heterogenous factors beyond documentation and legal status that combine to influence interaction between communities and the state.

After outlining the theoretical, methodological and empirical background to the study, the paper will use data from an ethnographic, multi-sited, study to present this argument in three parts. First, it will highlight the articulated nature of exclusion faced by ethnically Vietnamese communities in Cambodia, demonstrating in particular how statutory rights may be subsumed by political narratives and individual judgments of ethnicity. Secondly, it will demonstrate how these factors combine to produce collective mobilities which derive from insecure citizenship, but also actively elide specific differences in documentation and status. Finally, it will seek to explain these mobilities, arguing that, unlike ineffective citizenship, they are a form of statelessness that emerges in response to the combination of past, present and potential risk, inducing ethnically Vietnamese communities to rely on informal networks and livelihoods which make no use of their rights of citizenship.

\section{Moving Beyond Legalism: The Collective Mobilities of 'Liminal Statelessness'}

Reflecting its range and variety in the $20^{\text {th }}$ and $21^{\text {st }}$ centuries, the subject of statelessness has been approached through a number of lenses. Geographically bounded studies form a significant part of the 
literature, with studies on Somalia (Brons, 2001), Malaysia (Allerton, 2017; Allerton, 2014) and the border enclaves of India and Bangladesh (Shewly, 2017, 2016, 2013; Cons, 2013; Jones, 2009) being prominent examples. Furthermore, studies of statelessness amongst particular ethnic groups have been undertaken in numerous parts of Asia, with the Biharis in Bangladesh (Redclift, 2013; Hussain, 2009; Farzana, 2008, Paulsen, 2006) most prominent amongst academic studies, followed by the Rohingya in Myanmar (Parnini 2013; Rahman, 2010; Lewa, 2009) and Tamil in Sri Lanka (Kanapathipillai, 2009; Kanapathipillai, 1995). As in a number of these contexts, the literature on statelessness within Cambodia itself is limited, with only a small selection of academic works on the Vietnamese population (Berman, 1996; Amer, 1994) available, alongside a handful of more recent studies (Rumsby, 2015; Ang et al., 2014; Duoos, 2012; Sperfeldt and Nguyen, 2012).

In addition to these locally bounded studies, much of the literature on statelessness is more conceptual in framing. In particular, recent years have seen the rise of significant debate over the validity of de facto statelessness, a concept intended to extend the International Law Commission's (1954: 49) original de jure definition of 'a person not considered as a national by any state under the operation of its law'. Unlike those captured by this clear but somewhat restrictive typology, de facto stateless people have been described broadly as those who 'are, effectively, without a nationality' (Weissbrot and Collins, 2006: 252 [emphasis added]) because they 'are unable, or for valid reasons...unwilling to avail themselves of the protection' of a state (Massey et al., 2010: 61).

Whilst such efforts have been welcomed by many for the attention they bring to those excluded from the benefits of citizenship for cultural or political reasons, others have questioned the validity of this expanded categorization, on the basis that 'the (in)effectiveness of citizenship cannot lead to the rejection of the centrality of the legal bond' (Tucker, 2014: 7). Convincing evidence has emerged of how access to the rights of citizenship is structured and stratified according to a variety of social and economic conditions (Jayal, 2013), rendering the delimitation between ineffective citizenship and de facto statelessness unclear.

Further work is therefore required to clarify the condition of de facto statelessness. However, such is the complexity of the issue that no one perspective has been able to frame the debate in its entirety. Rather, discussions broadly reflect a literature divided into two areas: that which approaches the issue through international legal (Gruberg, 2011; Blitz, 2009; van Waas, 2009; Weis, 1979) and rights frameworks (Weissbrodt, 2008; Somers and Wright, 2008; Goldston, 2006) and that which explore it as a heuristic 
corollary to nationhood and citizenship (Redclift, 2013; Schneiderman, 2013; Hagmann and Korf, 2012; Staples, 2012; Belton, 2011; Blitz and Lynch, 2011; Blitz, 2011; Boyden and Hart, 2007). Although both have undertaken substantial reframing work in order to deepen understanding of the lived experience of statelessness, it is this latter camp that is perhaps of greatest relevance to the study of de facto stateless persons, seeking as it has not only to cast citizenship - and its absence - as 'historically contingent and socially constructed' (McConnell, 2009: 1094), but also to extend the origins of precarious citizenship beyond history and towards an engagement with the contemporary global economy.

From this position, it has been argued that 'the fundamental contradiction of postindustrial globalism' the mobility of some productive factors and state mediated stasis of others - makes the irregular migration that often precedes statelessness both 'a structural feature of the second era of capitalist globalization' (Donato and Massey, 2016: 7) and a key means for the state to 'recapitulate the reification of the state's authority and power by restating and entrenching national boundaries' (De Genova, 2002: 425). Statelessness so conceptualized therefore becomes less a question of the administrative gaps through which certain groups may fall and more one of the constructed disjunctures between nationhood and citizenship, born of tensions between the 'formal and substantive aspects' of place and state (Holston and Appadurai, 1999: 4).

Such themes have been addressed in some detail in the literature on undocumented migration (Papadopolous and Tsianos, 2007; Powers and Seltzer, 1998) and 'desperate mobilities' (Martin, 2012; 2011), which demonstrates how, rather than undermining the legal infrastructure of migration, the 'fraught' (Martin, 2012: 356) nature of extra-legal mobility underscores and justifies it. Nevertheless, the irregular migration and integration literatures are limited in their utility to the study of statelessness by a 'methodological nationalism' (Wimmer and Glick Schiller, 2002: 217) that prioritises transnational movement. Many stateless persons have never crossed a border and as various authors have argued (Jones et al., 2017; Lestrellin, 2011), it is often social rather than spatial boundaries that define 'who is in and who is out; who belongs and who does not; who is visible in the eyes of society and who is invisible' (Hammer, 2009: 4). What is necessary, therefore, is a theoretical foundation capable of linking the implications and determinants of everyday mobility to broader structures of economy and statehood.

In shaping this perspective, much is offered by the literature on semi-legality (Kubal, 2013; He, 2005) and liminal legality, wherein various authors (Torres and Wicks-Asburn, 2014; Menjivar, 2006; De Genova 2002) have emphasised how the "liminal" nature of legal status shapes the lifeworlds of those whose 
citizenship is incomplete. In a similar vein to Turner's (1987: 46) writings on 'the interstructural situation....betwixt and between' two conditions, the concept of liminality used in these studies to explore 'the gray areas between documented and undocumented' (Menjivar, 2006: 1004) as a means of shedding new light on the everyday manifestation of the state. Nevertheless, though nuanced and effective in their analysis, these approaches continue to place legal frameworks at the core of their approach. Liminality is understood in legal, rather than practical, terms and less attention is therefore directed towards understanding how statelessness is shaped by lived experience, as well as formal classification.

Otherwise put, what is required is a framework that transfers the concept of liminality from citizenship to statelessness itself, in order to interpret the complex contextual challenges posed by de facto statelessness. Above all, this must highlight how disadvantages engendered at multiple scales - including, but not limited to, domestic and international legal frameworks, global norms, and local prejudices shape and sustain exclusion from the state, creating a statelessness that, though partial, is wholly distinct from citizenship itself. Liminal statelessness, thus conceived, is a lens that extends liminal citizenship by highlighting how the 'in-between identities' (Torres and Wickes-Asburn, 2014: 195) of the stateless are engendered not through documentation directly, but through the collective, longitudinal, experience of documentation as it manifests in everyday life and work.

In this respect, the concept of liminal statelessness draws upon and mirrors the lens of the mobilities literature (Urry, 2012; Urry, 2007; Sheller and Urry, 2006; Hannam et al., 2006), wherein multi-scalar power dynamics have been linked with some efficacy to everyday norms and narratives of exclusion. Indeed, the framework is, in many respects, a study of the mobilities of statelessness in the vein of Shewly's (2016: 464) 'survival mobilities' of the India-Bangladesh borderlands. However, it also extends the conceptual frameworks of the mobilities literature in two ways. First, it uses the concept of liminal citizenship to demonstrate how structural economic inequalities and locally mediated narratives combine to influence mobility, a perspective which, as various authors have argued (e.g. Manderscheid 2014; Merriman 2014; D'Andrea et al. 2011), has been a relative weakness of the literature.

Secondly, it seeks to move beyond the individualistic perspectives that have tended to facilitate the emotional and discursive inquiries of the mobilities literature, to an analysis of the collective mobilities practiced by stateless communities. Otherwise put, it explores how the experience and meaning of movement may be defined collectively; incorporating and feeding back to the structural dynamics of legality and inequality. Whilst this perspective has formed part of sociological approaches for some time 
(e.g. Gama et al., 2016; Mogghaddam and Perrault, 1992; Wagner, 1986; Larson, 1979), the 'tension between individual and collective mobilities' (Holdsworth, 2013: 2) and in particular the reflexive interplay of this tension with the structures that engender movement has been relatively underplayed in the contemporary mobilities literature. This paper therefore aims to demonstrate its potential utility.

As such, the framework of liminal statelessness applied herein combines elements of the liminal citizenship and mobilities literatures in such a way that the shortcomings of each is ameliorated by the strengths of the other. Using this framework, the paper aims towards a deeper understanding of de facto statelessness by demonstrating that those thus afflicted are not merely subject to 'ineffective citizenship' in the present (Tucker, 2014: 1), but also the collective memory of past and potential structures. Indeed, as the evidence here will demonstrate, the collective mobilities characteristic of statelessness are not merely a historical legacy, but are produced by the ongoing, discursive interaction of past, present and potential risks; continually refreshed by state and private actors working separately or in combination. Thus, it demonstrates that the liminal statelessness experienced by the groups under study differs from liminal and ineffective citizenship in its resulting not from formal legislative ambiguities but from these structures as they are 'articulated' (Lunstrom, 2013; Selby, 2012) through the collective practice of mobility.

\section{Methodology}

Fieldwork for this paper was conducted in two phases: between July and August 2015, and in June 2017, in Phnom Penh. It encompassed interviews in four locations around the city, each known for its high density of ethnically Vietnamese communities. Three of these locations were selected following consultation with local researchers prior to the commencement of the research timeframe, whilst the fourth was identified during early interviews as an additional significant centre of ethnic Vietnamese population not previously considered. The names of the four areas have been changed to protect informants' anonymity. They are listed here as: Ktum, Trey, Nealika, and Trokoun.

In total, 40 semi-structured, qualitative interviews lasting between 20 and 40 minutes were conducted across these four areas over the first phase of fieldwork, with ethnically Vietnamese informants employed in fishing, petty trade, construction work amongst others occupations. During the second phase, interviews were conducted with a further 5 informants, one of whom was the head of a village under study, in order to capture both authority figures and to add longitudinal validity to the results. Each 
interview was conducted in Khmer by one of two, two person teams containing one native Khmer speaker and one proficient non-native speaker, a setup intended - following Hoggart et al. (2002) - to minimise the downsides of using field assistants (unmatched interpretations, mistranslations etc.), whilst maximizing the benefits of doing so, including knowledge of the local area and recent events therein.

In view of the inherent difficulties of researching stateless population (Van Waas et al., 2015; Van Liempt and Bilger, 2009) and bearing in mind the 'powerless or disadvantaged' status of the target informants, it was necessary to bear in mind that 'they may feel exploitation or derogation, or be skeptical about research' (Lee, 1993: 7). Consequently, ethnically Vietnamese informants were selected via a process of snowball sampling, as recommended by Faugier and Sargeant (1997) and Fleischer (1995) for the study of hard to reach or vulnerable populations. Initial informants of Vietnamese ethnicity - but whose legal status was relatively secure - were therefore identified as gatekeepers to subsequent informants of less secure status, a process intended to considerably shorten the process of building trust in hard to reach communities (Markova, 2009).

Moreover, in order to build trust in a context where institutions are viewed as hostile, no interviews were conducted with officials during the first phase of research. This was initially viewed as a means of 'building up trust in a setting with high levels of suspicion towards the researcher' (Bilger and van Liempt, 2009: 4). However, given the prominence of key authority figures in informants' accounts during the first phase and in particular the claims made about the ethnically mediated provision of documentation - interviews with authority figures gained importance during the course of the research. The second phase of research therefore saw the research team gain access to the testimony of a local authority figure in order to provide a degree of balance to the data. Although the uncertainty of Cambodia's current political climate contributed to refusals by authority figures to speak to interviewers in several cases, the key role of village heads in the everyday provision of documentation, together with the close correlation between the testimony of this authority figure with that of other informants render it an invaluable contribution to the study.

\section{Statelessness and the Vietnamese in Cambodia}

Statelessness is rarely a legal issue alone, but is bound up in the same histories, shared ideologies and cultures from which nationality is constructed. This tension between culture and law has been apparent from Cambodia's earliest post-colonial independence, when the 1954 nationality law requiring applicants for nationality to possess "sufficient" Khmer language skills was tightened via a 1959 amendment to 
specify that Cambodian nationals must speak the language "fluently" and to exhibit a "sufficient assimilation" of Khmer manners, customs, and traditions' (Amer, 1994: 214). Similarly, nationality laws are not only 'unclear' (JRS, 2013: 1) but underpinned by a pervasive myth of ethnic and cultural homogeneity (Kirchner, 2015; Ter Horst, 2008; Edwards, 2007) reflected not only in national discourse, but the country's institutions and the laws that govern them.

In particular, the interchangeability with which the dyads "Khmer" and "Cambodian" (JRS, 2013) and "nationality" and "citizenship" (CCHR, 2011) are used in Cambodia's nationality law reflects less legalistic negligence and more a pervasive national mindset in which culture, ethnicity and nationality are heavily conflated. This is backed by linguistic conventions operating at all scales, with Cambodia itself, for instance, being more commonly referred to as srok Khmer [the home of the Khmer people] than Kampuchea [Cambodia]. Most specifically, it is reflected in the 1993 constitution's references to Khmer citizens - a term with the potential to deny constitutional rights to the $10 \%$ of Cambodia who do not belong to the dominant ethnic group - and in the 1996 Law on Nationality, which grants jus sanguinis citizenship to those whose parents include at least one 'Khmer citizen' (Sperfeldt, 2017: 11).

Furthermore, the same law includes additional provision for jus soli citizenship, on the basis that both parents had been 'living legally' in Cambodia at the time of the applicant's birth. Nevertheless, 'the 1996 Law on Nationality does not stipulate what is meant by 'living legally' in Cambodia and what status or documents would be required to prove legal residence in the country' (Sperfeldt, 2017: 15). The level of evidence required is therefore largely at the discretion of the official in question, creating 'an impasse to many long-term residents who may fulfill the legal requirements for applying for citizenship, but who cannot produce proof of their birth in Cambodia (Sperfeldt, 2017: 15).

The result is constitutionally embedded exclusion for many ethnic minorities (Kirchner, 2015), but in particular the Vietnamese, who continue to be viewed as the object of historical animosity. Despite being the largest minority group in Cambodia, with recent figures indicating their numbers at 'up $5 \%$ of the total Cambodian population' (Rumsby, 2015: 2), Cambodia's ethnically Vietnamese population have for decades been disadvantaged by 'discriminatory' nationality laws (Berman, 1996: 874) a persistent 'antiVietnamese stand displayed by generations of Cambodian politicians' (Amer, 1994: 229) and even 'armed attacks' (Amer, 2006: 389) which continue to this day (Soth and Handley, 2017; Frewer, 2016; Eang, 2014).

Making use of these sentiments, 'royalists, conservatives, liberals and communists' have all profited from stoking fears of Cambodia's Eastern neighbor during Cambodia's short democratic history (Amer, 1994: 
229) and the present is no exception. The emergence of the currently dominant opposition, the Cambodian National Rescue Party [CNRP], has stoked anti-Vietnamese sentiment yet further, with party leaders' frequent use of the word "yuon" - a traditional Khmer word for Vietnamese people that is variously viewed as neutral, impolite, or actively derogatory - becoming ever more charged in the wake of the CNRP's defeat in 'the rigged elections of 2013' (Lewis, 2015: 8). Since that defeat, Cambodia's 'deep suspicion and hatred of the Vietnamese' (Frewer, 2016: 1) has manifested more frequently in action, with racial incidents, attacks, or even murder becoming 'fairly common' (Lewis, 2015: 8) in certain parts of the country.

Life for ethnically Vietnamese communities has therefore become increasingly difficult, as targeted attacks complement an institutional hostility which is not only rooted in law, but articulated by individual authority figures and underpinned by a hostile national discourse. As the following sections will demonstrate, passive opposition to acquiring documentation, harassment and discrimination by authorities, and the ever present threat of violence or expulsion, combine to compel the targets of discrimination to rely upon ethnically mediated networks for livelihoods, protection and support. As outlined below, this renders them subject to a multifaceted state of exclusion that is rooted in the multiscalar political economy, but entrenched by everyday mobilities.

\section{Heterogeneous Documentation and Articulated Bureaucracy}

A key feature of ethnically Vietnamese livelihoods in Cambodia is their geographical and historical diversity. Large Vietnamese communities exist along the Mekong and Tonle Sap rivers, encompassing sizeable populations in Kampong Chnang, Battambang and along substantial regions of the Eastern border (Ehrentraut, 2013). Alongside an ongoing history of trade, many of these communities date back to one or more distinct historical events, from the Vietnamese occupation of 1835-40, to the immigration of Vietnamese administrators during the French colonisation of 1863-1954 (Minority Rights Group, 1995), to the influx of Vietnamese migrants which took place during the People's Republic of Kampuchea [PRK] administration from 1979 to 1989 (Amer, 1994).

This variety is reflected in a complex landscape of citizenship, involving various combinations of documentation. There are four documents to which Cambodian citizens are entitled: a birth certificate, 
ID card, voting card and family book ${ }^{1}$, as well as a "letter of immigration" which constitutes sanctioned leave for non-citizens to remain for an indefinite period, but does not grant any rights. Entitlement to certain documents is, moreover, predicated on the possession of others. An ID card, for instance, cannot be processed without all other relevant documents. Few informants living in the communities under study held all of these documents and a number possessed none.

These differences in documentation produce a great variety of legal circumstances. However, de jure legal differences are not the basis of categorization herein. Rather, informants are grouped instead in terms of their arrival to Cambodia, as either first generation immigrants - referred to here as Vietnamese immigrants - or those born in Cambodia, referred to as Vietnamese Cambodians. Where both groups are referred to simultaneously, the term ethnic Vietnamese is used. The purpose of this taxonomy is to highlight how the mobilities and behaviours associated with statelessness cross-cut specific legal entitlements and documentary differences, manifesting in collective mobilities which are both characteristic and constitutive of liminal statelessness.

Unlike liminal citizens, therefore, the disadvantage of ethnically Vietnamese communities is rooted only partially in legality. Many of those who fall into this category have previously possessed documentation, or as outlined in section 5.3, continue to possess it. Nevertheless, those thus afflicted are disbarred from many of the benefits of citizenship: socially, they are excluded from mainstream schooling and the services of local law enforcement; physically, they are induced to live in the waterside margins of both rural and urban areas; and economically, they are prevented from accessing a formal sector which plays an increasingly important role not only for the younger people that predominantly serve it (Parsons et al., 2014), but also for the households and communities that depend on migrant salaries for both remittances and loan security (Parsons, 2016; Parsons and Lawreniuk, 2016b).

As one first generation immigrant explained, 'I am Vietnamese, so if I go to work in a factory, they won't accept me [yet things elsewhere] are getting tense. It's difficult to do business [and] there are fewer jobs now. Even construction work has fewer' (Woman, 48, Nealika). Similarly, as a 27 year old woman, resident in Phnom Penh for 20 years, explained, this:

'makes it very difficult. If you don't have an ID then you can't go and work in a factory. The whole family is the same: my mother isn't [really] working, just selling cakes and things around. My

\footnotetext{
${ }^{1} \mathrm{~A}$ family book is a document registered to the head of a household in which all members of a nuclear family are recorded as linked to a particular property. Its primary purpose is therefore registration of residency.
} 
father just plants vegetables [on the river bank]. My sister sells coffee in a mobile van and my brother is a carpenter' (Woman, 27, Trokoun).

In both cases, therefore, the consequences of inaccessible citizenship are not necessarily immobility or isolation, but precarity and informality. Those who find themselves in this situation rely to a significant extent on the maintenance of social and familial networks, both for work in their adopted country - where connections within the labour market are a vital means of finding work in the informal economy - and in obtaining access to their country of origin. Unable to access citizenship rights formally due to a lack of key documentation, they therefore depend entirely on the ability of friends or family members to vouch for them to officials. As one stated, for instance, 'when I visit Vietnam, my family comes to the border to tell the police that I am from Vietnam and then they let me in' (Woman, 27, Trokoun). However, whilst personal testimonies may be enough to facilitate a return, they do not constitute sufficient evidence for the renewal of documents. If the thread of communication breaks, therefore - as it eventually does in the case of numerous first generation informants - then their tenuous connection to the state breaks with it.

In this respect, long term first generation migrants share much with a second group, whose citizenship is limited or inaccessible: ethnically Vietnamese Cambodians born in the Kingdom, but still unable to obtain documentation due to the bureaucratic intransigence of official outlets. As one such informant explained: 'I was born in Cambodia, so I cannot get a Vietnamese ID card, but the Khmer officials won't make one for me either. They told me that if I had a birth certificate then they could do it for me, but I was born at home: my mother didn't go to hospital, so there are no records there to find' (Woman, age unspecified, Ktum).

The enormous political upheaval of recent decades has meant that home births - with all their future implications for accessing the rights of citizenship - are not unique to marginalized communities. However, for the ethnically Vietnamese, the history of non-documentation extends back far further. Many of those who possess no identification cannot even trace their family's initial arrival, recalling only that 'all of my ancestors were born in Kampong Chnang, but I never had any ID; only a family book' (Woman, 70s, Ktum). Under such circumstances, the lack of documentation becomes self perpetuating, with multiple generations born in Cambodia denied access to it:

'I was born in Kampong Cham. Now I have nothing left [there, though]. My parents have died already. I came to Phnom Penh in 1980. My family was sent to Kampong Cham during the war and came back to Phnom Penh...I never went to school but I can speak Khmer and Vietnamese as my parents are 
from Chau Doc in Vietnam. They came to Cambodia [as a family] in my grandmother's generation, so I don't know exactly when. I have no ID documents; [the authorities] never made them for me as they said I was Vietnamese. My husband is the same.' (Woman, 43, Trokoun).

Similarly:

'I don't have any Vietnamese documents because I was born here. I also don't have Khmer ID because I have been to make it, but they never give it [to me]. I was summoned to make an ID card [previously] and paid \$10. I've done it many times, but I cannot get it...The last time I went they told me it would cost $\$ 10$, but after I gave it to them, I asked when I can get the ID card back and they said they don't know' (Man, 36, Nealika).

Though distinct in their personal and historical migratory histories, then, respondents in each of the above categories are united by their lack of an ID card, a key piece of documentation whose absence 'makes it very difficult to get a job' (Man, 28, Nealika). In many cases, their inability to procure one was attributed primarily to economic reasons. Disproportionate figures of ' $\$ 100, \$ 200$, or $\$ 300$ ' (Man, $29, \mathrm{Ktum}$ ) were frequently cited, leading potential applicants to state that 'getting a Khmer ID card will cost a large amount of money and I don't have that money, so no ID' (Woman, age withheld, Ktum).

Moreover, official intransigence and foot dragging means that even finding the funds 'does not ensure that you will get [the document]' (Man, 29, Ktum). Rather, in some cases 'the document that [informants] paid $\$ 200$ - 300 for was fake' or 'had the wrong name or wrong address, so if anybody follows up on that when we are caught, we will be in trouble again' (Man, 29, Ktum). More commonly, officials simply provide no documentation at all, despite 'guarantees' of prompt delivery (Man, 56, Nealika). As one woman explained:

'I applied for a Khmer ID card, paid money, wrote the application, but on the day I went to collect it, they said it was lost. I applied [again] 15 days ago, but when I go they just pass me from one person to the next, tell me to talk to another person, then another one, then another one.' (Woman, 39, Trokoun)

Underpinning these accounts is a strong sense that these issues had a basis in ethnicity. As informants stated, 'the authorities raise many problems and it is very expensive... but only for Vietnamese people, the people round here' (Woman, 20, Ktum). In some cases, this may manifest in active threats of deportation and extortion, as described by a resident of Nealika: 
'I don't have any ID because I don't have any money. If we [make] an ID card, we have to give a lot of money to officials. Beforehand, we paid $\$ 100$ or $\$ 200$, but we never got the ID card...The officials came here and offered to make us an ID card - this was 5 years ago - and at the time they guaranteed that we would get the card. But they also threatened that it we don't make the ID card, then they will come and take us back to Vietnam. At that time, we were afraid, so we had to do it...To pay for it we had to borrow money from other people: around \$250. It took a long time to pay it back; more than a year.' (Man, 56, Nealika).

A crucial feature of this widely noted bureaucratic hostility towards ethnic Vietnamese in Cambodia is that decisions as to who should be subject to the unreliability, delays and harassment reported by respondents rest largely in the hands of individual officials or, more specifically, in the aesthetic judgments they make as to applicants' ethnicity. As the respondent above continued, officials decide upon this 'by their appearance and language....after two or three words they will know' (Woman, 39, Trokoun). Indeed, an official confirmed this perspective, stating that:

'The ones who rent land here, generally we don't give a letter [of residence] to them at all. Even if they own their land, if they're not Cambodian nationals I can't do anything for them, even a family book. If they are from Kampuchea Kraom ${ }^{2}$ [though], I can do it for them...[It is possible to tell because]...their way of speaking is different and the way they look is different. Also their colour [is different]. Kampuchea Kraom [people] are black, whereas Vietnamese [people] are white' (Village Head, Trokoun)

Given that Kampuchea Kraom has been a part of Vietnam for some 200 years, this official's testimony highlights how everyday narratives of nationalism are articulated in the sphere of documentation. Moreover, they demonstrate the impact of aesthetic narratives in the process of obtaining documentation; a system that can present a major impediment to citizenship, for those who do not fit the received aesthetic template of ethnicity. As one woman explained, for instance, she was excluded from citizenship by the very ethnic stereotypes designed to include her:

I was born in Vietnam, in Kleang province and left more than 30 years ago...I only have Khmer documents, as my Vietnamese ones have expired, but just a family book, no ID card...I'm not really

\footnotetext{
${ }^{2}$ Kampuchea Kraom is a part of southern Vietnam which belonged to Cambodia until the early $18^{\text {th }}$ century. The area remains populated by ethnic Khmer inhabitants who retain strong linguistic and cultural links to Cambodia. It retains a prominent place in the Cambodian national mindset and is viewed by many Cambodians as an unlawfully annexed part of Cambodia.
} 
Vietnamese, I am Khmer Kraom [from Kampuchea Kraom], but when I was called to do the ID card, the official looked at me from head to toe and said that I was Youn.' (Woman, 59, Nealika).

\section{The Collective Mobilities of Exclusion}

That so much of citizenship in practice relies upon aesthetic judgments of ethnicity, rather than documentation itself is something that is well understood by Cambodia's ethnic Vietnamese. Moreover, assessments of this sort are not only made of those seeking documents themselves. Rather, since 'the surge in political unrest' which occurred in early 2014 'led to a spike in attacks on Vietnamese' (Campbell, 2014: 1), the practice of these racial assessments has become a daily part of life for many, as discourse on the limited value of documentation is internalized even by those who possess everything necessary to prove their citizenship. As one such informant, a woman of 26 who was born and had lived all her life in Phnom Penh, explained:

"If I was moved "back" to Vietnam then I could not live there as I could not adapt to life there. I worry about that even though I have all the documents [of citizenship]. When I was working [recently], a Vietnamese guy came up to me and asked if I had documents. He said it didn't matter because he knew people where he was from who had been sent back even though they all had documents' (Woman, 26, Nealika).

Moreover, the difficulty of obtaining an ID card contains an intergenerational element. Numerous respondents reported cases wherein 'my daughter is just a baby and [like us] she doesn't have a birth certificate. Very few around here do' (Woman, 23, Ktum). Similarly, as a long term immigrant married to a Cambodia-born husband - both Vietnamese Cambodians - explained: 'my sons have not yet reached the age of making an ID card, but my husband, like me, doesn't have one. In our village in Kandal maybe only 4 out of a 100 people have an ID card' (Woman, 39, Chamkar Doueng).

This is an issue which manifests early in the life of a child. As parents attested, long before a personal ID card can be made the need to officially register children with a school presents an issue for many parents of Vietnamese ethnicity. As they explained, they find it "hard to send their children to school because you need every document [to register]' (Woman, 70s, Ktum). Consequently, most ethnically Vietnamese children attend informal schools run by members of the local community. As outlined by a local official, 'in this village, there is one Vietnamese teacher who has a class, so all the Vietnamese [children] go there. 
I've never seen any Vietnamese [children] go to the state school' (Village Head, Trokoun). Not only does this mean that 'life will be difficult for them' (Woman, 23, Ktum) but their lack of a formal education ultimately serves to 'affect their future' (Man, 29, Ktum) by locking generations of families into informal sector work.

A palpable example of this situation is visible in Ktum, where multiple extended families live on boats docked semi-permanently to the river bank. In one case, despite two of the family's three generations being born in Phnom Penh, 'having no relatives in Vietnam and never having visited Vietnam...all the family work by peeling the skin off garlic [cloves] and then selling them to restaurants' (Woman, 20, Ktum). The family's inability to prove their citizenship therefore necessitates that they 'do a business now that is not related to any documents', which means relying on personal - often ethnically, or nationally mediated - networks such as this one, wherein 'the owner of the garlic business is Vietnamese' and the family have 'known him for a long time' (Woman, 20, Ktum).

Thus, despite a clearer claim to citizenship, they practice the mobilities of exclusion in much the same manner as their first generation counterparts. Indeed, the similarly informal labour practices shared by Cambodia's ethnic Vietnamese families born abroad and in Phnom Penh highlights how the formal legality of documentation is 'articulated' (Lunstrom, 2013; Selby, 2012) through the everyday experience of local bureaucracy. Although the legal status of each of these groups differs significantly, they are united through their shared experience of prejudicial attitudes on the part of authority figures, which is not based on legal or documented status, but individually mediated judgments of ethnicity.

This manifests both actively and passively: on the one hand, they are systematically denied access to a key element of documentation and thus indirectly to the variety of economic benefits and securities it brings. On the other, moreover, they are subject to periodic crackdowns and harassment by police, which - though the ultimate outcome depends to a significant extent upon documentary status - are nevertheless applied on a blanket basis, without consideration of the subtleties of legality. For instance:

'[The crackdowns] didn't happen round here, but a little further away, closer to the market. When they were caught, they were asked if they had any ID or documents [on them at the time]. If they had then they let them go, but if they didn't then they kept them in prison for 3 or 4 months then sent them to Vietnam. I know some people who had some documents and were arrested; their families took their documents to the police and got them back [but] there is no compensation. 
The officials should ask in advance if they have any documents, but they don't. They just arrive and take them away' (Man, 29, Ktum).

As such, suspicion of the authorities and the need to take measures to avoid arrest transcends the possession of documentation, binding ethnically Vietnamese communities together in a manner that elides the rights theoretically endowed to individuals by formal legal status. Indeed, as members of these communities explained, 'some people have documents, some people don't have them. Even those people over there, they have documents, but they aren't usable. For the people who do and don't have documents it's the same' (Woman, 68, Trey).

The impact of this liminal status on the everyday mobilities of those affected is significant. Not only are 'the owners of some workplaces...scared to take people who don't have ID' (Woman, 68, Trey, restricting many people to 'just cleaning somebody's house or doing wage labour' (Man, 25, Ktum), but constraints on property ownership impede both short term movement and long term stability. In particular, obtaining access to a vehicle is problematic for some. As informants complained: 'we can't buy land if we have no ID card, we can't even buy a moto because when you buy one you need to make a number plate and ID is needed for that' (Man, 29, Ktum).

Thus, the lack of a single piece of physical documentation generates patterns of movement that bind Cambodia's ethnic Vietnamese into cycles of informality by inhibiting access to residential property. This process creates areas - such as those under study - in which only ' $10 \%$ [of people] are Khmer out of 300 or 400 families' due to their attractiveness to the undocumented. As residents explain, in these areas 'it's easy to run a small business and...go from place to place [because] nobody, not even the police, cares where you're going' (Woman, 21, Trokoun).

However, communities such as these are not bound to collective mobilities on a purely reactive basis. Indeed, similar patterns are not observed amongst poor and informal settlements of predominantly Khmer ethnicity. Rather, over the long term these patterns of association, labour and movement become self reinforcing, creating a shared ethnic identity which comes explicitly to supersede nationality over time in some cases. As a man born in Battambang explained, for instance, a lifetime of shared mobilities has engendered him to accept rather than reject the ethnic classification externally imposed upon him:

'I am from Battambang and my father and mother are also from Battambang. I came to Phnom Penh 20 years ago as it was very difficult in the village. There was nothing to do; no rice land. When we came to Phnom Penh, we came here, to this area. I don't have a job and my family has already died. 
My mother is the only one working, selling petty goods...I came here very young and all around me there are Vietnamese people. Now I feel like I am Vietnamese.' (Man, 28, Nealika).

A second woman, also from Battambang, related a similar process, highlighting in particular the ongoing role of documentation in determining her identity:

'I am from Battambang. I left to go to Vietnam during Pol Pot's regime, then in 1981 I came to Phnom Penh and have stayed in this place ever since... When I was younger, I had to pay money to the police every year. That payment was just for Vietnamese people, not for Khmers, but if they didn't get your payment they would arrest you. [Now I feel that] I am Vietnamese, living in Cambodia. I feel more Vietnamese [than Cambodian] because I don't have any documents' (Woman, 63, Nealika).

As such, the liminal status faced by much of Cambodia's ethnically Vietnamese population has an agglomerating effect which brings together Vietnamese immigrants and Vietnamese Cambodian people possessing various levels of documentation and with a variety of different migratory histories. The twin incentives of accessing the informal labour market and avoiding police harassment generate collective mobilities that foster a shared identity and entrench a sense of ethnic distinction from other Cambodians. However, they are not generated in the present alone. What follows shall explore how a legacy of environmental and man- made risk contribute also to these mobilities of exclusion.

\section{Past, Present and Potential Risk in the Production of Contemporary Mobilities}

One of the key features of ethnically Vietnamese communities in Cambodia is their association with water. All of the communities studied during the course of this research were located either on - in the case of those living on boats - or next to Phnom Penh's lakes and waterways, where land is in the public domain and property rights are either firmly in the domain of the state, or insecure due to the competition of regulatory frameworks, as in the case of river banks and areas partially flooded during the course of the year (So, 2010).

The use of public, or semi-public, areas in this way is not unique to ethnically Vietnamese communities: beggars, informal, and even some salaried migrant workers regularly reside in such areas as one element within a wider migration strategy (Parsons and Lawreniuk, 2016a). However, what distinguishes the communities explored here is their unbroken retention of waterside livelihoods, outside of the domain of property rights, over periods of many years and often encompassing multiple localities. Many of those who currently live in undocumented riverside areas have done so for generations in similar circumstances 
or, as they explained, they 'have no land [now] because we used to live near the river bank, on a floating house above the river' (Woman, age unspecified, Ktum).

These long term, multi-local waterside livelihoods are not predicated on poverty alone. Rather, the specific mobilities of Cambodia's ethnically Vietnamese communities reflect a combined legacy of manmade violence and environmental risk that has left a clear impression on documentary records. In particular, the legacy of administrative violence left first by the Khmer Rouge conflict (Tyner and Rice, 2016) and thereafter by multiple incarnations of the state (Sperfleldt, 2017) is a key factor in contemporary statelessness. Upheavals, enforced deportations, and multiple changes of government have left returnees from Vietnam as undocumented strangers in a country neither they nor their families had ever previously left. For example:

'I was born in Phnom Penh [but] my parents were born in Kampong Chnang. Four generations [of my family] have lived in Cambodia and maybe before that the first generation was perhaps from Vietnam...Before the war, my parents had all the documents of Cambodian nationality. But during the war, all these documents were lost. After the war, they returned from Vietnam and [people] called them Vietnamese.' (Man, 55, Nealika).

For those excluded by the state in this way, echoes of Cambodia's war torn $20^{\text {th }}$ century continue to be felt in the form of heightened exposure to contemporary shocks, both natural and manmade. Either undocumented or classified as 'foreign residents' after their return from exile abroad (Sperfeldt, 2017), many ethnically Vietnamese communities had little choice but to settle in marginal areas characterized by weak property rights and informality. The heightened environmental risks faced by residents of these areas means that property loss, including loss of documentation, is common. Younger people in particular, many of whom were born in Cambodia, lose their access to citizenship in this way, with numerous informants explaining that they 'had a birth certificate, but...lost it in a house fire' (Man, 25, Ktum) such as that which destroyed much of the Ktum community in 2002.

The high prevalence of such accidents is intertwined with marginality. Many ethnically Vietnamese communities' residences are, by dint of their informality, generally constructed from wood and lack mains electricity. Alternative energy sources - candles or portable generators rigged to temporary lighting constitute major sources of urban environmental risk (Flower and Fortnam, 2015) and render their users chronically vulnerable to fire. Even where mains electricity is available, it tends to be privately installed and operated - often via an arrangement wherein 'someone takes the electricity from the state and runs 
it through our house, then comes to take payment every 15 days' (Woman, 31, Ktum) - making it far less safe than an official supply.

Moreover, their waterside location brings the additional risk of flooding. As one respondent, born in Ktum, explained: 'we used to have documents, but we lost them...We lost everything during flooding and now all we are left with is our grandparents' voting card' (Woman, 23, Ktum). Compounding this threat for the many people living in boats or moored structures is the additional risk of sinking during storms and heavy rain. As one woman who experienced this related, for instance: 'we lost all of our documents when the boat sank in 2008. The rain was heavy and the boat broke at night and sank into the water. Nobody knew where anything was' (Woman, 27 Ktum).

Accounts such as these demonstrate the everyday risk faced by Cambodia's ethnically Vietnamese communities. However, it is often not the loss of the documents, but the inability to replace them that engenders de facto statelessness. As a second young woman explained:

'When I was young, we lived along the river, but our house was burnt down. We lost everything, including all of our documents. We cannot get replacements, because officials are unwilling to do it for us. It happened when I was 7 years old. Many people were affected by this situation because many of the houses nearby were burnt down' (Woman, 20, Ktum).

As this testimony highlights, the reluctance of officials to replace documents, even for those Vietnamese Cambodians who 'had them before' (Man, 70, Ktum), holds a significance beyond individual cases. The knowledge that lost documentation will not be replaced is an insecurity that extends even to those possessing a full set of documents, thereby ensuring that potential as well as actual environmental risk becomes imprinted on the mobilities of Vietnamese Cambodian communities. Knowing that they face precarity of citizenship, ethnically Vietnamese communities are incentivized towards stasis and agglomeration, building contingencies by constructing networks and connections to low level authority figures which can only be gained over an extended period of residency, even if it means poorer conditions, or higher levels of environmental risk. In particular, the need to build informal linkages in this way means that Vietnamese Cambodian enclaves often develop a long term presence in areas which are either state owned, or possess marginal property rights. As a resident of Trey explained:

'If you live here for a long time, then they will make you some kind of documents, but ID no; other kinds of documents. I don't care about any documents [though], just living. Even if you don't have any 
documents, if the police and the village chief know you for a long time then nobody makes problems for you' (Woman, 68, Trey).

The efficacy of personal protection of this sort was widely repeated, with multiple respondents asserting that 'besides the village chief, no one is looking out for us' (Woman, 23, Ktum). Indeed, as a lifelong resident of Ktum explained, 'for me it was easy [to get documents] because the village chief and commune chief knew me very well as I have lived here a long time. [But] for people who just come here for a short time it is difficult...If the village chief and commune chief don't know you, then no [documents]' (Woman, 28, Ktum). Nevertheless, the actions of authorities and private enterprise constitute a counter mechanism to such informal protective strategies. Numerous respondents reported frequent harassment by police and evictions by companies wishing to take over the land on which they lived. For example:

'I was born in Battambang, but I moved to Vietnam in 1974 and then back to Cambodia in 1983 to live in Chak Angkrea Kraom...At first I sold vegetables [in the area] but I was moved away because they took the land to build a Thai factory. Our land wasn't really affected [by the plans] but they didn't my kind around so they just moved me away' (Woman, 65, Nealika).

Thus, despite strong incentives to build durable communities and long term linkages, the combined effects of short term and insecure work, evictions, vulnerability to natural and manmade disasters, and police and administrative harassment has induced many Vietnamese Cambodians to lead highly mobile lives. Even younger informants reported 'having already moved seven times' (Woman, 20, Ktum) in response to the development of the area. Similarly:

'We have lived in a few places, all around Ktum, moving 4 or 5 times [since 2008]. The house owners want to build new houses, so we must move, as the new houses will be more expensive so there is no chance to stay' (Woman, age unspecified, Ktum).

Individually enacted evictions such as these are common. Even more so, however, are those planned and enforced on a larger scale by a combination of state authority and private enterprise. In particular, those living on boats have been forced to move on a number of occasions in recent years, as part of police crackdowns, or simply as a means to ensure that such communities remain peripheral in an expanding city. As a resident who had experienced state eviction explained: 
'We used to live in Ktum, but the officials told us we couldn't live here anymore and sent us here [Trey]. We brought our house with them: the police officers just towed our house here' (Woman, 31, Trey).

On other occasions, evictions occur through private sector mechanisms and development projects which displace entire waterside communities. One of the largest of these is a new bridge building project, peripheral developments related to which threaten to displace large tracts of ethnically Vietnamese settlements towards the south of Phnom Penh. As a resident of Ktum, close to the now completed bridge, explained:

'We used to live in Nealika, but we were moved on because somebody wanted to develop that place. So we moved here, but now we are being moved on again because of the bridge: somebody wants to develop a garden round here. We found out a year ago and there are perhaps three years left. We don't know where we will go [and] there's no compensation; we're just made to leave' (Woman, 70s, Ktum)

Even those who have been given no specific notice of future evictions or developments have come to expect them as routine, stating that 'I will live here until one day [in the future] when this place is filled in for development. Then I will need to find another place to live' (Woman, 43, Chamkar Doueng). This compulsion towards constant mobility constitutes an impediment to building livelihoods, but also a means by which official abuses go under-reported, even within afflicted communities. As one respondent explained:

'Many people had this happen to them, but they keep it a secret. That kind of thing they never talk to each other about because they always move from place to place, so they never know their neighbours at all' (Man, 56, Nealika).

Thus, despite their need for stability, many members of these communities therefore develop transient mobilities, impeding their ability to find mutual solutions to the issues they face as a community. Given the importance, noted above, of developing long term personal relationships with officials, this rapid mobility constitutes a further de facto constraint on citizenship, preventing ethnically Vietnamese Cambodian communities from constructing the linkages they require to supersede their lack of documentation. 
In this way, the combination of past, present and potential risks traps Vietnamese Cambodian communities in perpetually liminal statelessness. A history of discrimination through both conflict and legality has left many with no, or partial, documentation and contemporary articulations of state institutions render this problematic to resolve. The marginal mobilities enacted in consequence compound this exclusion and the informal solutions found by stateless communities are continually undermined by state and private actors. In consequence, they remain perpetually in limbo, unable either to move freely or remain. Quite apart from documents, it is this loss of control over mobility that constitutes the everyday experience of lost citizenship.

\section{Conclusion}

This paper has drawn together the viewpoints from Phnom Penh's ethnically Vietnamese communities to demonstrate two points of relevance to the literature on statelessness. First, it has demonstrated that de facto statelessness in this context is engendered not directly through documentation or legal status, but through a wider range of factors, including political narratives of nationhood and aesthetic judgments of ethnicity. Consequently, many features of everyday mobility are shared by both undocumented first generation immigrants and ethnically Vietnamese Cambodians who have never crossed a border. In this way, the evidence here has helped to highlight a distinction between liminal citizenship - which tends to be rooted in individually mediated, legal uncertainty - and liminal statelessness, which is engendered by a wider variety of factors blocking access to citizenship rights.

Secondly, since these cultural and narrative dimensions of statelessness are experienced communally, the evidence here demonstrates that the everyday experience of statelessness is in large part mediated on a group, rather than an individual, basis. The collective mobilities of exclusion this engenders leads ethnically Vietnamese communities to pursue informal livelihoods, schooling and patterns of residence, even where their statutory rights or documentation might facilitate more formal choices in the short term.

From a theoretical perspective, this position helps to ameliorate the tension between the structural and narrative dimensions of movement, highlighting how discourse at multiple scales may influence the ability to access individual economic or legal endowments. Moreover, the concept of collective mobilities also admits a longitudinal dimension to the nexus of exclusion and mobility, demonstrating as it does how events experienced by a community in the past may shape the present behavior of individuals. From this standpoint, the paper has argued, thirdly, that the contemporary livelihoods of liminally stateless Vietnamese in Cambodia reflect a combination of past and present environmental risk, and the potential 
risk of being unable to prove one's citizenship in the future due to the difficulty of replacing documentation.

The plight of Cambodia's ethnically Vietnamese communities therefore has a wider relevance. By demonstrating that their enduing marginality is generated not by unitary historical events, or discrete legal discordances, but by ongoing processes in which both the state and ideas of nationhood more broadly play a role, their case demands a reassessment not only of statelessness, but of citizenship also. The everyday lives of the excluded demonstrate 'the cracks and fissures in the fiction of coterminous nations, states, and territories' (Scott, 1998: 380) by showing that citizenship is not only a formal construct, but one discursively produced and culturally mediated through use. Otherwise put, seeing the state as do the stateless clarifies not only exclusion but inclusion also, by revealing something of the multiscalar narratives by which a citizen is made. 


\section{References}

Allerton, C. (2014). Statelessness and the lives of the children of migrants in Sabah, East Malaysia Tilburg Law Review, 19(1-2), 26-34.

Allerton, C. (2017). Contested statelessness in Sabah, Malaysia: irregularity and the politics of recognition Journal of Immigrant and Refugee Studies. ISSN 1556-2948 (In Press)

Amer, R. (1994). The ethnic Vietnamese in Cambodia: a minority at risk? Contemporary Southeast Asia, $16(2), 210-238$.

Ang C., Weill, N. and Chan, J. (2014) Limbo on Earth: An Investigative Report on the Current Living Conditions and Legal Status of Ethnic Vietnamese in Cambodia. Investigative Research Report No 2. Phnom Penh: Minority Rights Organisation [MIRO]

Belton, K. A. (2011). The neglected non-citizen: statelessness and liberal political theory. Journal of Global Ethics, 7(1), 59-71.

Berman, J. S. (1996). No place like home: anti-Vietnamese discrimination and nationality in Cambodia. California Law Review, 84(3) 817-874.

Bilger, V. and van Liempt, I (2009). Conducting research among smuggled migrants in the Netherlands and Austria in Van Liempt, I. and Bilger, V. (eds.) The Ethics of Migration Research Methodology: Dealing with Vulnerable Immigrants Brighton: Sussex Academic Press.

Blitz, B. (2009). Statelessness, protection and equality Forced Migration Policy Briefing 3 Oxford: Refugee Study Centre.

Blitz. B., and Lynch, M. (2011). Statelessness and Citizenship: A Comparative Study on the Benefits of Nationality Cheltenham: Edward Elgar Publishing.

Boyden, J., \& Hart, J. (2007). The statelessness of the world's children Children \& Society, 21(4), 237-248.

Brons, M. H. (2001). Society, Security, Sovereignty and the State in Somalia: from Statelessness to Statelessness? Dublin: International Books.

Cambodian Centre for Human Rights [CCHR] (2011). False Promises: Exploring the Citizenship Rights of the Khmer Kraom in Cambodia Phnom Penh: CCHR.

Cons, J. (2013). Narrating boundaries: Framing and contesting suffering, community, and belonging in enclaves along the India-Bangladesh border. Political Geography, 35, 37-46.

D'Andrea, A., Ciolfi, L., \& Gray, B. (2011). Methodological challenges and innovations in mobilities research. Mobilities, 6(2), 149-160.

De Genova, N. (2002). Migrant" illegality" and deportability in everyday life. Annual Review of Anthropology, 419-447. 
Donato, K. M., \& Massey, D. S. (2016). Twenty-First-Century Globalization and Illegal Migration. The Annals of the American Academy of Political and Social Science, 666(1), 7-26.

Duoos, T. (2012). To Be Determined: Stories of People Facing Statelessness Phnom Penh: Jesuit Refugee Services [JRS].

Eang Mengleng (2014). Vietnamese Man Killed In Racist Mob Attack The Cambodia Daily 17/02/2017.

Edwards, P. (2007). Cambodge: The Cultivation of a Nation, 1860-1945. Honolulu: University of Hawaii Press.

Faugier, J., \& Sargeant, M. (1997). Sampling hard to reach populations. Journal of advanced nursing, 26(4), 790-797.

Farzana, K. F. (2008). The neglected stateless Bihari community in Bangladesh: victims of political and diplomatic onslaught. Journal of Humanities \& Social Sciences, 2(1), 1-19.

Fleischer, M. (1995) Beggars and Thieves: Lives of Urban Street Criminals. Madison: University of Wisconsin Press.

Flower, B. and Fortnam, M. (2015). Urbanising Disaster Risk: Vulnerability of the Urban Poor in Cambodia to Flooding and Other Hazards Phnom Penh: People in Need

Frewer, T. (2016). Cambodia's Anti-Vietnam Obsession: Anti-Vietnamese sentiment dominates Cambodia, even among otherwise progressive NGOs and political groups. The Diplomat.

Gama, J. I. C., Avalos, M. L. R. and Contreras, H. J. R. (2016) Considerations on Collective Mobility versus Individual Mobility: New Actors and Forces. Paper presented at the $11^{\text {th }}$ CTV Conference: Back to the Sense of the City, Krakow, 6-8 ${ }^{\text {th }}$ of July 2016.

Gruberg, S. (2011). De Facto Statelessness among Undocumented Migrants in Greece. Geo. J. on Poverty L. \& Pol'y, 18, 533-549.

Hagmann, T. and Korf, B. (2012) Agamben in the Ogaden: Violence and Sovereignty in the Ethopian-Somali Frontier Political Geography 31(4), 205-214.

Hammer, P. (2009). Development as Tragedy: The Asian Development Bank and Indigenous People in Cambodia in Hammer, P. (ed.) Living on the Margins: Minorities and Borderlines in Cambodia and Southeast Asia Center for Khmer Studies, Wayne State University Law School Research Paper No. 09-06. Accessed on 19/10/2016 at [https://ssrn.com/abstract=1371595].

Hannam, K., Sheller, M., \& Urry, J. (2006). Editorial: Mobilities, immobilities and moorings. Mobilities, 1(1), $1-22$.

He, X. (2005). Why Do They Not Comply with the Law? Illegality and Semi-Legality among Rural-Urban Migrant Entrepreneurs in Beijing. Law \& Society Review, 39(3), 527-562. 
Hoggart, K., \& Lee, S. L. and Davies, A. (2002). Researching Human Geography Oxford: Oxford University Press.

Holdsworth, C. (2013). Family and intimate mobilities. London: Palgrave Macmillan.

Holston, J.and Appadurai, A. (1999) Cities and Citizenship. in Holston, J. (ed.) Cities and citizenship. Durham: Duke University Press.

Hussain, K. (2009). The end of Bihari statelessness Forced Migration Review, (32), 30-31

Hutt, D. (2016). The Truth about Anti-Vietnam Sentiment in Cambodia: a closer look at a subject that often does not get enough sustained attention The Diplomat 20/10/2016.

Institute on Statelessness and Inclusion [ISI] (2014). The World's Stateless The Netherlands: Wolf Legal Publishers [WLP].

International Law Commission (1954) Nationality Including Statelessness: Report on Present Statelessness. Report appearing in The Yearbook of the International Law Commission, volume 2.

Jayal, N. G. (2013). Citizenship and its discontents: An Indian history. Boston: Harvard University Press.

Jesuit Refugee Service [JRS] (2013). Statelessness in Cambodia: June 2013 Brief accessed on 17/02/2017 at [http://www.jrscambodia.org].

Jones, R. (2009). Sovereignty and statelessness in the border enclaves of India and Bangladesh Political Geography, 28(6), 373-381.

Jones, R., Johnson, C., Brown, W., Popescu, G., Pallister-Wilkins, P., Mountz, A., and Gilbert, E. (2017). Interventions on the state of sovereignty at the border Political Geography 59, 1-10.

Kanapathipillai, V. (1995). The repatriation of Indian Tamil plantation workers from Sri Lanka to India The Cambridge Survey of World Migration, 326-331.

Kanapathipillai, V. (2009). Citizenship and Statelessness in Sri Lanka: The Case of the Tamil Estate Workers London: Anthem Press.

Kirchner, L.M. (2015). Living on the margins: On the Status and Standing of Minorities and Indigenous Peoples in Cambodia Phnom Penh: Heinrich Böll Foundation.

Kubal, A. (2013). Conceptualizing semi-legality in migration research Law \& Society Review, 47(3), 555587.

Larson, M. S., \& Larson, M. S. (1979). The rise of professionalism: A sociological analysis Berkley: University of California Press.

Lee, R. M. (1993). Doing research on sensitive topics. London: Sage. 
Lestrellin, G. (2011). Rethinking state-ethnic minority relations in Laos: internal resettlement, land reform and counter-territorialization. Political Geography, 30(6), 311-319

Lewa, C. (2009). North Arakan: an open prison for the Rohingya in Burma Forced Migration Review, (32), 11-13.

Lewis, A. (2015) Historical patterns of the racialisation of Vietnamese in Cambodia, and their relevance today.

Centre for Ethnic and Racial Studies [CERS] working paper 2015. Accessed on 17/02/2017 at [http://cers.leeds.ac.uk/working-papers].

Lunstrum, E. (2013). Articulated sovereignty: extending Mozambican state power through the Great Limpopo Transfrontier Park Political Geography, 36, 1-11.

Manderscheid, K. (2014). Criticising the solitary mobile subject: Researching relational mobilities and reflecting on mobile methods Mobilities, 9(2), 188-219.

Manly, M., \& van Waas, L. (2014). The State of Statelessness Research Tilburg Law Review, 19(1-2), 3-10.

Markova, E. (2009). The 'insider' position: ethical dilemmas and methodological concerns in researching undocumented migrants with the same ethnic background in Van Liempt and Bilger (eds.) The Ethics of Migration Research Methodology: Dealing with Vulnerable Immigrants Brighton: Sussex University Press, 141-154.

Martin, C. (2012). Desperate mobilities: logistics, security and the extra-logistical knowledge of 'appropriation'. Geopolitics, 17(2), 355-376.

Massey, H. 2010. UNHCR and De Facto Statelessness. Department of International Protection. United Nations High Commissioner for Refugees, LPPR/2010/01. Accessed on 06/26/2017 at http://www.unhcr.org/4bc2ddeb9.html.

McConnell, F. (2009). Governments-in-Exile: Statehood, Statelessness and the Reconfiguration of Territory and Sovereignty. Geography Compass, 3(5), 1902-1919.

Menjívar, C. (2006). Liminal Legality: Salvadoran and Guatemalan Immigrants' Lives in the United States. American journal of sociology, 111(4), 999-1037.

Merriman, P. (2014). Rethinking mobile methods Mobilities, 9(2), 167-187.

Minority Rights Group (1995). Minorities in Cambodia United Kingdom: Manchester Free Press.

Moghaddam, F. and Perreault, S. (1992) Individual and Collective Mobility Strategies among Minority Group Members The Journal of Social Psychology, 132(3), 343-357

Ovensen J, Trankell I, Ojendal J. (1996). When every household is an island: social organisation and power structures in rural Cambodia. Uppsala Research Reports in Cultural Anthropology 15 Uppsala University: Uppsala.

Papadopolous, D. and Tsianos, V. (2007) The Autonomy of Migration: the Animals of Undocumented Mobility. in Hickey-Moody, A. and Malins, P. (Eds.). Deleuzian Encounters: Studies in Contemporary Social Issues. Basingstoke: Palgrave Macmillan, 223-235. 
Paulsen, E. (2006). The citizenship status of the Urdu-speakers/Biharis in Bangladesh. Refugee Survey Quarterly, 25(3), 54-69.

Parnini, S. N. (2013). The crisis of the Rohingya as a Muslim minority in Myanmar and bilateral relations with Bangladesh. Journal of Muslim Minority Affairs, 33(2), 281-297.

Parsons, L. (2016). Mobile inequality: Remittances and social network centrality in Cambodian migrant livelihoods. Migration Studies, 4(2), 154-181.

Parsons, L., \& Lawreniuk, S. (2016a). The village of the damned? Myths and realities of structured begging behaviour in and around Phnom Penh. The Journal of Development Studies, 52(1), 36-52.

Parsons, L. and Lawreniuk, S. (2016b). Love in the Time of Nokia: Cultural Change as Compromise in a Cambodian Migrant Enclave, Population, Space and Place pp.1-18.

Parsons, L., Lawreniuk, S., \& Pilgrim, J. (2014). Wheels within wheels: Poverty, power and patronage in the Cambodian migration system. The Journal of Development Studies, 50(10), 1362-1379.

Powers, M. G., \& Seltzer, W. (1998). Occupational status and mobility among undocumented immigrants by gender. International Migration Review, 32(1), 21-55.

Urry, J. (2007). Mobilities. London: Polity.

Urry, J. (2012). Sociology beyond societies: Mobilities for the twenty-first century. London: Routledge.

Rahman, U. (2010). The Rohingya refugee: A security dilemma for Bangladesh. Journal of Immigrant \& Refugee Studies, 8(2), 233-239.

Redclift, V. (2013). Statelessness and Citizenship: Camps and the Creation of Political Space London: Routledge.

Rumsby, C. (2015). Acts of Citizenship and Alternative Perspectives on Voice among Stateless Vietnamese Children in Cambodia Institute of Statelessness and Inclusion Working Paper Series No. 2015/04 accessed on 17/02/2017 at [http://www.institutesi.org/forum/workingpapers.php.].

Shneiderman, S. B. (2013). Himalayan border citizens: Sovereignty and mobility in the Nepal-Tibetan Autonomous Region (TAR) of China border zone Political Geography, 35, 25-36.

Scott, J. C. (1998). Seeing like a State: How Certain Schemes to Improve the Human Condition have Failed New Haven: Yale University Press.

Selby, D. (2012). Patronage, face, vulnerability: articulations of human rights in Thailand. The International Journal of Human Rights, 16(2), 378-400.

Sheller, M., \& Urry, J. (2006). The new mobilities paradigm. Environment and planning A, 38(2), 207-226.

Shewly, H. J. (2013). Abandoned spaces and bare life in the enclaves of the India-Bangladesh border Political Geography, 32, 23-31. 
Shewly, H. J. (2016). Survival Mobilities: Tactics, Legality and Mobility of Undocumented Borderland Citizens in India and Bangladesh. Mobilities, 11(3), 464-484.

Shewly, H. J. (2017). Life in de facto statelessness in enclaves in India and Bangladesh. Singapore Journal of Tropical Geography, 38(1), 108-122.

Soth Koemsoeun and Handley, Erin (2017) False Kidnapping Hysteria "Not Helping Anything", Police Say. The Phnom Penh Post, 31/07/2017.

So, S. (2010). Land rights in Cambodia: an unfinished reform Asia Pacific Issues 97, 1-7.

Sperfeldt, C. (2017). Report on Citizenship Law: Cambodia Italy: European University Institute.

Sperfeldt, C. and Nguyen, L. (2012). A Boat Without Anchors: A Report on the Legal Status of Ethnic Vietnamese Minority Populations in Cambodia Under Domestic and International Laws Governing Nationality and Statelessness RegNet Research Paper No. 2014/50. Available at [https://ssrn.com/abstract=2514121]

Staples, K. (2012). Retheorising Statelessness: A Background Theory of Membership in World Politics: A Background Theory of Membership in World Politics. Edinburgh: Edinburgh University Press.

Ter Horst (2008). Weaving into Cambodia: Trade and Identity Politics in the (post-) Colonial Cambodian Silk Weaving Industry Unpublished Ph.D. Dissertation. VU University, Amsterdam.

Torres. R.M., \& Wicks-Asburn, M. (2014). Undocumented Students' Narratives of Liminal Citizenship: High Aspirations, Exclusion, and "In-Between" Identities. Professional Geographer, 66 (2) 195-204.

Tucker, J. (2014). Questioning de facto statelessness. Tilburg Law Review, 19(1-2) 276-284.

Turner, V. (1987) Betwixt and Between: the Liminal Period in Rites de Passage. In Mahdi, L.C., Foster, S. and Little, M. (eds.) Betwixt and Between: Patterns of Masculine and Feminine Initiation. Chicago: Open Court.

Tyner, J. A., \& Rice, S. (2016). To live and let die: Food, famine, and administrative violence in Democratic Kampuchea, 1975-1979. Political Geography, 52, 47-56.

Van Liempt, I. and Bilger, V. (2009). The Ethics of Migration Research Methodology: Dealing with Vulnerable Immigrants Brighton: Sussex Academic Press.

Van Waas, L. (2009). Statelessness: A 21st century challenge for Europe Security and Human Rights, 20(2), 133-146.

Van Waas, L. E., Rijken, C. R. J. J., Gramatikov, M. A., \& Brennan, D. (2015). Researching the nexus between statelessness and human trafficking: The example of Thailand The Netherlands: Wolf League Publishers. 
Wagner, D. (1986). Collective mobility and fragmentation: A model of social work history. Journal of Sociology and Social Welfare, 13, 657-700.

Weissbrodt, D. S. (2008). The Human Rights of Non-Citizens USA: Oxford University Press.

Weissbrodt, D. and Collins, C. (2006) The Human Rights of Stateless Persons Human Rights Quarterly, 28, 245-276.

Wimmer, A., \& Glick Schiller, N. (2002). Methodological nationalism and beyond: nation-state building, migration and the social sciences. Global networks, 2(4), 301-334. 